\title{
Crime Control or Crime Culture TV?
}

\section{Nic Groombridge1}

\begin{abstract}
In criminological and in popular or media discourse CCTV is seen to be 'working'. Sometimes concern is raised about the civil liberties issues raised by such surveillance - for instance, in its extension from shopping malls to police cells. This paper reviews the criminological contributions to the debate but goes on to cross the borders of criminology into media and cultural studies by examining popular cultural texts which focus on or incorporate CCTV and surveillance as themes. Examples include: Big Brother, The Simpsons, J.G. Ballard's Super Cannes and Ben Elton's Dead Famous. That is, whether CCTV works or not, it has become part of the cultural repertoire. Some thoughts are offered on the efficacy/'ethicacy' of CCTV but more on the intertwined nature of crime and media and the recognition that CCTV is a medium which has become part of our culture.
\end{abstract}

\section{Introduction}

The Simpsons episode 'Homer Badman' sees our 'hero' accused of sexual assault by a young woman. In reality he was pulling a sweet (the Venus de Milo Gummi Bear!) from the back pocket of her very tight jeans in pursuit of his notorious greed. He is only saved a finding of guilt by the eventual appearance of video footage shot by a neighbour which shows greed not lust to be his sin of choice. His wife, Marge, declares: 'The Courts may not work but when everyone is videoing everyone else justice will be done'. The neighbour admits to regularly filming couples in cars and is later denounced on the very TV show that was to submit Homer to its TV 'stocks' or 'pillory' (See Peelo and Soothill, 2000 on the public scaffold and the part of the media as 'crowd'). We see Homer watching the show at home and joining in the denunciation of his saviour/neighbour. The denouement to Ben Elton's novel Dead Famous (2001) - based on the Big Brother TV show format - transfers the detective/suspects showdown from the sofas of the vicarage drawing room to the sofas of the live studio of House Arrest. The se examples are indicative of the widespread acceptance of surveillance cameras as part of the (street) furniture. That is like the good documentary film-maker they merge with the wallpaper better than a fly on the wall. A running joke of two flies (on the wall!) discussing the programme was how the second Big Brother series used the 'gap' between programme and adverts where the sponsor is named.

\footnotetext{
${ }^{1}$ St Mary's College, Strawberry Hill, a College of the University of Surrey. nic.groombridge@ freeserve.co.uk.
} 
Away from the popular cultural field in the less-surveyed alleys of criminology investigations tend to focus on the effectiveness of CCTV distracted only by the occasional complaints of the civil liberties lobby. The first part of this paper will examine some of that criminological literature and the civil liberties arguments. Criminology tends to the pragmatic and civil liberties towards political principles. However, a lot of that literature ignores the growing body of social theory on surveillance. The second section therefore examines some of that developing social theory and additionally to related cultural/media and film theory. We then turn in the third section to issues of a specifically socio-cultural nature: the extent to which - whether CCTV works or not, at catching or deterring criminals, whether our civil liberties have been compromised or not - CCTV has become part of the mental and physical landscape. The concluding fourth section offers the Director's Cut - not the studio version tested on audiences but not the last word either. Editing is an infinite process. It is in the plasticity of digital media that resistance might secure a walk-on part. Those who are familiar with the criminological might skip this section and readers familiar with social theory of surveillance can skip the second section. It is in section 3 that the pervasiveness of surveillance as a cultural theme, specifically of CCTV, is addressed. However, it is to criminological research we first turn.

\section{Criminology versus civil liberties}

Policy-makers, press and politicians tend to see CCTV as effective and invite criminologists to endorse those claims. Civil libertarians concentrate on the threat posed by surveillance. Groombridge and Murji (1994a and 1994b) wrote about CCTV in terms that neither accepted the efficacy nor the threat arguments. That is the trade off is too simply made between crime control and civil liberties. However, this impartiality makes for difficulties in gaining access to systems for empirical study. It was the experience of doing the research for Groombridge and Murji (1994b) that alerted the author to the hyped claims for CCTV. Such claims included unjustified claims about the as yet uncompleted research - made by Council and police, including the use of emotive campaigning to secure funding for the cameras - but also the more mundane (under)(mis)use of the cameras, such as using high quality cameras as part of the traffic monitoring system (such incidents also noted by McCahill, 2002). Subsequent work on CCTV, particularly for evaluations, has tended to be from the pragmatic wing of criminology. Research is done generally to show that 'it works'. This is partially to do with what system owners and operators want and the domain assumptions of many criminologists or the simple need to sustain research in the modern university. An example of the tensions involved in this can be seen in Mawby where at the press launch of the Doncaster CCTV Evaluation the unnamed academic responsible is quoted as saying 'You'll get no sound bites from me' (2002: 144) and then insisting on speaking very technically and qualifying every point. Whereas the local police commander was very media savvy and handed out 'best of' tapes (whilst seeking assurances that the tapes would not be seen later on TV!). 
Clearly these tapes would of have been edited to show some 'action' yet Norris and Armstrong (1999) show over 592 hours of their monitoring at three varied sites very little action (45 'deployments' leading to 12 arrests). Six hundred and ninety eight people were surveilled as of primary concern. Only $7 \%$ were women and the majority were young white men but there was over-representation of black youth and the 'scruffy' or 'subcultural'. Whilst 30\% were watched for 'crime' reasons (mostly 'suspicion of' rather than 'caught in the act') and $22 \%$ for 'order' reasons (usually actual), the greatest number of incidents of surveillance were for 'no obvious reason'. The working assumptions of the operators are based on targets' behaviour or appearance being 'out-of-place' in the operator's 'normative ecology'. Thus male on male violence was often reported to police but not violence to women from men they were with. So even if surveillance systems are all seeing they are not all knowing.

Some of these points are adumbrated in the edited collection (Norris, Moran and Armstrong, 1998). The editors connect the rise of CCTV to 'a drift away from the Old Penology'(7) Graham (1998) traces the interrelated supply (media and manufacturers) and demand (public and officials) pressures that establishes and normalises CCTV as the 'silver bullet', 'technofix' or 'fifth utility' with a case study of Tyneside. He examines the 'stories' of six schemes with their different purposes and funding partnerships. This 'patchwork quilt' leads to a displacement from rich to poor areas, urban to rural. Armstrong and Giulianotti (1998) examine the homogenised and consumer-orientated spaces that are modern football stadia and the history of policing 'hooliganism'. All this before Rupert Murdoch's bid for Manchester United closed the circuit on televised football. They note the distancing effect of video surveillance that lead, at Hillsborough, to the tragic misinterpretation of events. Ditton and Short (1998), Skinns and Gill (1998) and Turpin (1998) respectively present evaluations of schemes in Airdrie, Doncaster and in shops in Sheffield and Leeds. Ditton and Short show crime reduction in the immediate area and no displacement to closely adjoining areas. Interestingly they sampled 30 offenders who showed good knowledge of the areas covered by the system and surprisingly high rates of approval for the system - as potential victims of public order offences. A change in the fighting culture away from the town centre and large-scale affray was noted. In Doncaster crime reductions could not be conclusively tied to CCTV but a 'halo' round the immediate area and displacement further afield could be. Interestingly 47 'help points' enabled the public to talk to the control room. Properly installed - including mobilising staff support - CCTV could affect the context and mechanisms of shop theft.

Moving away from Town Centre and Shopping Mall CCTV we find a more particular use in Newburn and Heyman's study (2001). They studied the before, after and processual issues involved in fitting CCTV cameras in the cells and corridors of the custody suite at Kilburn Police Station; cameras were also trained on the custody sergeant's desk. This very close observation of gaolers and prisoners and of prisoners by gaolers and of gaolers observing prisoners clearly raises the issues of civil liberties. In particular toilet areas were under observation and both sexes were on camera as were potential viewers of monitors. Those issues are made even more apparent if we consider the possibility of 
opening out the circuit to the Internet ${ }^{2}$ for an example of a 'jailcam' with footage from the cells of Sheriff Joe Arpaio's Cells where he helpfully warns us that we may see violence or sexually inappropriate behaviour). This could be seen as a way of introducing 'lay visiting' by technology in the way that 'management-by-walking-about' has been replaced by remote sensing of keystrokes or the monitoring of calls ('for training purposes').

The preceding paragraphs indicate some of the range of growing criminological engage ment with CCTV. Some of it explicitly seeks to counter the civil liberties and human rights arguments by pointing to the benefits. Certainly this is the position of political supporters of CCTV and their cheerleaders in the media. However, Simon Davies and others are adamant about the disbenefits, indeed the threat posed by CCTV ${ }^{3}$. Mark Thomas comedian, writer and TV documentary maker encourages activists through his website to use the Data Protection Act to demand footage from any CCTV camera they feel may have 'captured' them ${ }^{4}$. Finally the surveillance camera players (motto: 'Distrustful of all Government) stage plays/protests to give the cameras something to watch $^{5}$. They are not alone: David Shenton, cartoonist, graphically (Guardian July 1995) renders an imagined amateur dramatic group using the CCTV cameras as an audience and independently the author imagined something similar ${ }^{6}$. The question that may arise eventually for media lawyers is who gets the appearance and repeat fees?

Where criminologists have turned their attention to civil liberties it is often with a nostalgic modernism that believes that potential breaches can be held in check by bureaucracy or legislation as Norris and Armstrong (1999) hope. As their research shows our current protection is substantively provided by the sheer volume of images (they estimate of 17 million hours of footage a week generated by cameras!) and the laxity of the operators. However, expert systems (that could learn to identify 'the usual suspects') and automated face recognition systems should reduce these lacunae.

It is not easy to encompass the pragmatic criminological effectiveness argument within the principled human rights/civil liberties objections - though as we shall see - Newburn and Heyman (2001) do engage with the issue. A different pragmatic discipline economics - may eventually show that the loss of liberty is not worth the crime control gain but here be turn to some recent social theory.

\section{$\underline{\text { Back to Top }} \underline{\text { Skip to Cultural }}$}

\footnotetext{
${ }^{2}$ See: http://www.crime.com

${ }^{3}$ Privacy International: http://www.privacyinternational.org/issues/cctv/

${ }^{4}$ Mark Thomas Comedy Product: http://www.mtcp.co.uk/campaigns/dataprotection.htm\#cctv

${ }^{5}$ Surveillance Came ra Players: http://www.notbored.org/the-scp.html

${ }^{6}$ Author's homepage: http://www.groombridges.freeserve.co.uk/democratic\%20male\%20gaze.htm
} 


\section{Surveilling the surveyors or surveying the surveillers: social theory and the cameras}

This section examines some of the sociological theory of surveillance - some of which predates CCTV, but which seems to presuppose it - before turning to media/cultural and film studies views of surveillance, the gaze and looking. These latter approaches often deploy a psychoanalytic frame, often a specifically feminist one, and focus on the gendered nature of to-be-looked-at-ness. But first the tension in social theory between those who see surveillance in negative terms and those prepared to admit to more positive assessments. This, more subtly, reflects some the arguments between criminology and civil liberties. Thus we find Tagg raising the spectre of the State:

What gave photography its power to evoke a truth was not only the privilege attached to mechanical means in industrial societies but also its mobilisation within the emerging apparatuses of a new and more penetrating form of the state. (1999:245)

This position might be contrasted with that of Lyon (1994) who kept the Orwellian nightmare of 1984 at bay with a Foucauldian emphasis on discipline but has moved on (Lyon, 2001) to incorporate some of the arguments about risk society from Beck. He divides modernist social theory on surveillance into these often interconnected approaches: the nation state, bureaucracy, 'technologic' and political economy (Lyon, 2001:10-113). These are discussed below before examining postmodern approaches.

All these modernist approaches see the increased routinisation of the lives of individuals and the part that computers increasingly play as part of the modernist project but each emphasises different aspects. Thus Dandeker (1990), from a war studies perspective, concentrates on the military value and origins of surveillance. When applied to totalitarian regimes this gives rise to the concern about the Orwellian Big Brother. Lyon makes a literary allusion - Kafka - when examining the bureaucratic approach, which owes its theoretical roots to Weber and his 'iron cage'. One complaint of the civil liberties lobby is against CCTV is 'function creep' (Ellul, 1980) so Davies (1995) notes the use of CCTV in Kings Lynn to pursue motorists over the use of unexpired portions of parking tickets (An 'offence' I have since committed in Kings Lynn). Whether this, third modernist strand - the 'technologic' - is essentialist cannot detain us here but it does emphasise that anything that can be controlled by technology will find itself increasingly controlled by technology. Lyon appositely notes 'policing requires increasingly that all citizens be supervised, in the interests of apprehending more efficiently those who behave criminally.' (2001:111). The fourth strand, political economy, concentrates on the reproduction of the class interests of Capital.

Lyon (2001:114) credits Poster with recognising the discursive possibilities in Foucault's panoptic metaphor - the symbolism of databases - and therefore the postmodern approach to surveillance. Broadly these approaches deny agency to the individual or intent to the State or Capital. Thus digital data serve to further fragment the unified and unique identity of the individual; no longer Mr or Mrs 'So-and-so' but the hip replacement, the 
suspect, the credit risk, the lottery winner. Such digital data allows for post and ad hoc manipulation - to the fear of many - but the emphasis in Bogard (1996) - relying heavily on Baudrillard - is on simulation. That is the possibility of using the technology for hyperreal purposes - to manipulate the data in advance, to produce an appearance of reality that masks the absence of a real referent. This is theoretically possible and is highly advanced in some postmodern theory but there is little evidence that it has actually been done in practice. Simulation does occur but it remains based on past events or models and its greatest use has been in simulation games such as SimCity. Indeed Lyon (2001:52) warns such theorists (without mentioning any names) against the danger of 'being seduced by their own metaphors'. Whilst one film (The Matrix) made much of computer gaming, a more recent one (Minority Report) imagines a high tech future crime prevention which relies on the older mental 'technology' of psychics (or 'precogs').

So whilst the increased speed of computing offers greater potential for prediction there is little evidence of foreseeing or dromology as Virilio (1986) calls it. Indeed Norris and Armstrong (1999:121) make this note:

00.42 Two white male s aged 16 and dressed casually but with hoods ... are followed ... The operator sees in them a 'result' and as they pass a cluster of parked cars mutters to the screen they are visible on 'have a go, have a go'. They disappoint him.

That is rather than preventing crime (and the camera may well have in this instance) the action orientation of the operator wants the suspects to 'have a go'. The cameras digital capacity has not outrun time and predicted the actions of the youths. The normative rules that Norris and Armstrong note may have predicted a 'result' but it is as much the psychic drives of the operator that influences who is 'followed' - stalked if you like. Whilst Norris and Armstrong recognise the attraction of CCTV as a visual medium (1999: 67-70) they make no use of theories of the visual; and it is to these we now turn.

So whilst postmodernists are correct to note the potential fluidity of the digital the decisions of CCTV operators and the pleasure given to TV viewers of CCTV/reality shows derive from the image created by the digital code. Here we deploy a media/cultural studies approach which grants greater play to the unconscious of the viewer - of films; but also, it is argued, of CCTV monitors too. A key text is Laura Mulvey's (1999) feminist appropriation of Lacan's post-structuralist extension of Freud's work. However, let's introduce her by a more straight-forwardly Freudian contribution on the pleasures (and ensuing guilts) of looking.

In the unconscious, to look at an object may mean various things, the most noteworthy of which are as follows: to devour the object looked at, to grow to like it (be forced to imitate it), or conversely, to force it to grow like oneself. (Fenichel, 1999:329)

More specifically Fenichel argues, 'Very often sadistic impulses enter into the instinctual aim of looking; one wishes to destroy something by means of looking at it' (1999:330). 
This might lead to other metaphors for CCTV than panoptic or Orwellian. Only the most convinced Freudian would go as far as seeing in the Eye 'another symbol for the terrible, devouring female genital'. Yet more may be taken by his other suggestions from the same sentence: 'the object which turns people into stone is very often a glaring eye (basilisk, snake, hypnotist)' (1999:334). These would work well in the context of discussions about the 'chilling' effect of CCTV. Moreover, without specific reference to female genitals but to the Mother more generally; we might see male resistance to CCTV as anxiety as to what this simultaneously threatening and desirable woman might see the naughty boy do.

Mulvey takes a feminist and structuralist view of the same area also starting from Freud, noting he: 'associated scoptophilia with taking other people as objects, subjecting them to a controlling and curious gaze' (1999:381) which she then uses to examine how men - and particularly women - are seen on screen. Men are seen to be active and the male audience to identify with them whereas women are passive - that is, to-be-looked-at. Leaving aside the debate within film studies about the particulars of this - including work on how the female audience views women and men, let alone queer readings - let us examine her discussion of Rear Window. Her 'reading' is quoted at length below and its relevance to CCTV will be picked up through a further 'reading' of the film's text.

In an analysis of Rear Window, Douchet takes the film as a metaphor for the cinema. Jeffries is the audience, the events in the apartment block opposite correspond to the screen. As he watches, an erotic dimension is added to his look, a central image to the drama. His girlfriend Lisa had been of little sexual interest to him, more or less a drag, so long as she remained on the spectator side. When she crosses the barrier between his room and the block opposite, their relationship is reborn erotically. He does not merely watch her through his lens, as a distant meaningful image, he also sees her as a guilty intruder exposed by a dangerous man threatening her with punishment, and thus finally giving him the opportunity to save her. Lisa's exhibitionism has already been established by her obsessive interest in dress and style, in being a passive image of visual perfection; Jeffries's voyeurism and activity have also been established through his work as a photo-journalist, a maker of stories and captor of images. However, his enforced inactivity, binding him to his seat as a spectator, puts him squarely in the fantasy position of the cinema audience. (1999:387)

This forms only a small part of Mulvey's argument but it suggests itself as a metaphor for CCTV and particularly the operators. An alternative reading is that whilst Lisa (played by Grace Kelly) is 'eye candy' for Jeffries and the male audience she is clearly active where he is not. He is passive. He is restricted to his wheelchair with his broken leg and in shot 5 of the film (Sharff:1997) a broken camera is seen. For Lemire (2000:68) he is figuratively castrated. He is not a symbol of male potency but its opposite.

Therefore if we read back the work of Mulvey and Fenichel into Norris and Armstrong we can enrich their findings. Of the 689 people targeted for surveillance only 49 were 
women. Of these women it is thought that $10 \%$ were targeted for 'voyeuristic' reasons (1999:114). Norris and Armstrong do not define voyeurism. However, in a discussion of a videotape found in the drawer of the head of security of Harvey Nicholls department store - featuring 'lingering close ups' of the late Princess of Wales (1999:59) - and elsewhere in the book, voyeurism is seen as a general characteristic of TV viewers or a specific perverse sexual orientation of an individual. Within a psychoanalytic framework the earlier discussion of the operators hope for a 'result' can be seen as more generally voyeuristic or scoptophilic, that is subjecting people to a curious controlling gaze. Themes of the passive impotence of the CCTV operator - compared to the active criminal or police officer - can now be seen in a different light.

These theories have been developed in response to popular cultural artefacts such as film and TV and we now turn to both visual and textual examples of the widespread nature of CCTV. Norris and Armstrong (1999:3) mention Hitchcock's Rear Window in passing and Lyon (2001) mentions SimCity as an example on at least five occasions but neither really engage with the cultural. And as we shall see the cultural has long embraced surveillance as a topic and more recently CCTV as a technology and integral plot device.

\section{$\underline{\text { Back to Top } \quad \text { Back to Surveilling }}$}

\section{The True men and women Show}

a burgeoning photographic industry could be divided between the domain of artistic property whose privilege, resting on copyright protection, was a function of its lack of power, and the scientifico-technical domain, whose power was a function of its renunciation of privilege. (Tagg, 1999:246)

It is the argument of this article that this separation between the rational/bureaucratic elements of CCTV and the affective/aesthetic/entertainment can no longer be sustained by analysts and commentators. As been noted a number of theorists have adverted to cultural engagement with surveillance or used examples from popular culture to make their points. Historical examples speak of more 'innocent' times as this plot summary of Bathing Girls Hurdle Race (1898) shows: 'During the height of the summer season our camera secured a series of amusing bathing scenes at Far Rockaway, of which this is the first. It shows a company of girls in stunning bathing suits in a race over the sand. ${ }^{7}$

The examples here are piled up, almost listlike, not to illustrate a point but to be the point. A further methodological point here is that no research was done for this section That is no specific attempt was made to locate examples ${ }^{8}$. The examples given are therefore serendipitous but evidence of the extent to which CCTV features as a motif/prop/deus ex

\footnotetext{
${ }^{7}$ Summary written by AMB Picture Catalogue (1902) featured on: http://us.imdb.com/Plot?0238851

${ }^{8}$ For instance Google offered 1.5 million pages on 'reality TV' 14 April 2002 but see also: http://moby.curtin.edu.au/ ausstud/mc/reviews/features/index.html
} 
machina within popular culture ${ }^{9}$. Because of the 'naturalistic' method of gathering the material for this section the majority of the examples are UK based but most of the shows 'cop' shows mentioned below have their local equivalents. Thus Cavendar and Fishman (1998) set the historical and social context of these programmes, drawing together the earliest radio programmes, film noir and TV series as varied as 1950s Dragnet and 1980s Hill Street Blues as antecedents. They note the credibility that Robert Stack brought to his hosting of Unsolved Mysteries from portraying Elliot Ness in the crime fiction The Untouchables. Moreover, Hill Street Blues is seen to have been influenced by a documentary, The Police Tapes. Due credit is given to European shows which can be seen as the direct ancestors of the genre including Crimewatch UK, Opsporing Verzocht (Netherlands) and Témoin No.1 (France); all granted a chapter apiece. They conclude that such shows draw on all the above and tabloid journalism but: 'are not news. They often violate basic journalistic practices' (p14).

Dovey argues that 'the dissemination of surveillance type images across the factual TV schedules is based on the widespread acceptance of the idea of CCTV as visual evidence.' (2001:136). Whilst this quote relates to the popularity of reality TV shows we shall see that CCTV features as parts of shows or as plot devices or part of the mise en scene of many films and adverts. Thus in the week beginning Sunday 20 January 2002 (when this was first drafted) we find: Sunday, The World's Wildest Police Videos 8:00 - 9:00 Channel 5, Tarrant on CCTV 9:30 - 10:00 ITV1; and on Wednesday, What not to Wear 8:30 - 9:00 BBC2. The latter is a fashion make-over show but with secret filming before and after. Other weeks offer other examples and video catalogues reveal further examples of the genre such as Police Camera Action, all in addition to the self-sanctifying Crimewatch UK.

But any TV addict can name shows which rely on CCTV footage or the promise of reality (more likely on the internet versions of some shows). Here are a few that promise a sight of the true man and woman: Big Brother, Survivor, Eden, Temptation Island, Candid Camera. These 'reality' shows themselves have become the subject of fictional treatments themselves, thus The Truman Show ('A man who lives happily in an island community discovers that he is the star of an all-day TV soap opera, and that his wife, friends and neighbours are all acting their parts'. ${ }^{10}$ ). Recently aired as The Experiment has been the BBC's recreation of the social psychology experiment of Zimbardo where the randomly allocated guards and prisoners quickly and violently come to act out their roles ${ }^{11}$.

However, perhaps, less well known to an adult audience is the TV show Bailey Kipper POV which features an early teenage boy who has his own control room and hidden cameras around his parent's house ${ }^{12}$. These are not used to see the primal scene, nor even

9 There may be more and better examples - do email them to: nic.groombridge@ freeserve.co.uk.

${ }^{10}$ CNN Movie Database: http://www.cnmovies.com/ search/filmdetails.asp?ID=293300

${ }^{11}$ Stanford Prison Experiment: http://www.academicpress.com/inscight/11082001/graphb.htm; www.stanford.edu/dept/news/report/news/may2/zimbardo-52.html;

http://www.realityblurred.com/archives/2001 $10 \quad 14$ index.shtml;

http://www.prisonexp.org/.

12 Bailey Kipper POV: http://us.imdb.com/Details?0118264 
spy on his teenage sister but used to augment the story and embellish his point of view (POV) with digital manipulations of a cartoon nature - distorted face, smoke from ears etc. $\mathrm{He}$ is seen not as a CCTV operator or scoptophilic pervert but more a TV producer manqué. The neighbour who films and therefore saves Homer Simpson is denounced as a pervert.

The evidential quality of TV is seen in the use by cricket now of such technology and recent plans to increase the power of the third umpire (in the pavilion watching the TV replays) over that of those actually on the pitch. The more plainly voyeuristic use of cameras is to be seen in the many webcams (including the jailcam mentioned above). Whilst some of these are covert (or claimed to be) others are set up for exhibitionistic or educational purposes. Thus the first woman to give birth on the internet 'Elizabeth' did so for America's Health Network Interactive ${ }^{13}$, but receiving rather more attention was the offer of British glamour model - Jordan - to give birth on the net on a pay-per-view basis.

A number of recent advertisements have used CCTV cameras as part of the 'plot'. These two car adverts are typical. The 'vava voom' campaign in 2002 for the Renault CLIO features a camera and control room focussing in on a young man's bedroom to see that his lassitude calls for some 'vava voom'. Cue despatch of Renault Clio. A few years earlier as part of Nissan's 'Ask before you borrow it' campaign (see Groombridge, 1998 on the relevance of such adverts as evidence of a joyriding culture). The opening shot is black and white - it is a CCTV monitor recording the progress of a young man around a car lot. The voice-over refers to the way to take away a car. The man tries the handle, gets in. The picture becomes full colour as the salesman offers him the keys for a test drive. Normality - legal and chromatic - is restored.

At a 'higher' cultural plane we find a conference at the Tate Modern on 9 March 2002 on Surveillance and Control to address how various surveillance technologies have influenced new media art practice ${ }^{14}$. IT artists Marko Peljhan (Slovenia), Kate Rich (Australia / UK) and Julia Scher (USA), investigative journalist, Duncan Campbell (UK), media theorist, Eric Kluitenberg (Netherlands), and Konrad Becker from Public Netbase (Austria). Obviously the conference was made the subject of a webcast.

Returning to popular culture we find Marx (1995) perceptively noting the surveillance theme in many popular songs from 'Santa Claus is coming to Town' to Sting's 'Every Breath you Take'. Moreover, returning to Rear Window he notes the theme tune is 'To See you is to Love You'! However, none of these refers directly to CCTV but a search of the Amazon website offers this album, I Think I See Myself on CCTV by Disciplin A Kitschne $^{15}$.

We continue the listing process by reference to two recent novels. The first, Super Cannes (Ballard, 2000), has much to say about modern life through a somewhat

\footnotetext{
${ }^{13}$ See discussion on: http://www.time.com/time/community/transcripts/chattr061798.html

${ }^{14}$ Tate Modern Surveillance and Control conference: $\mathrm{http}$ ://www.tate.org.uk/audiovideo/surveillance.htm

${ }^{15}$ Amazon UK: http://www.amazon.co.uk/exec/obidos/ASIN/B000024NEG/qid=1026294573/br=3lqid=1026294573/sr=10-1/ref=sr ri b/026-5432505-3487662
} 
sur(hyper)real style but makes some telling points about CCTV. The second - Elton's Dead Famous (2001) - quite shamelessly bases itself on the Big Brother TV format so the research for that simply involved watching the TV. Super Cannes specifically has this to say about CCTV: 'Representative Democracy had been replaced by the surveillance camera and the private police force' (2000: 38). This exchange between characters deals with some of the practical issues:

'There are four hundred cameras at Eden-Olympia. Scanning the tapes for a one-shoed man, or even a man in his socks, will take a great many hours of overtime'.

'Then the system is useless'.

'It may be Mr Sinclair. The cameras are there to deter criminals not catch them.' (2000: 58)

And this final quote touches upon another issue that will be returned to in the conclusion. Not whether CCTV works but the impact it has while 'working':

'There's no civic sense here.'

'There is.' Halder pointed to a nearby surveillance camera. 'Think of it as a new kind of togetherness.' (2000: 184)

Some of the same issues are handled more comically in Dead Famous. One of the Contestants, 'Woggle' is recognised as wanted by the police. They enter the Peeping Tom house (as it is called) to arrest him and the other contestants vie to give him advice on his arrest. David, an actor, warns the police he will remember what they look like should anything befall Woggle. 'It sounded great, and it would have sounded even better if the leading copper had not brought David down to earth by pointing out that since the arrest was being recorded by six separate video cameras he did not think that there would ever be a problem identifying the arresting officers. (2001: 116). In due course one of the contestants is murdered and the police are notified first by internet viewers. That is the watching world have been unpaid CCTV operatives.

Mathiesen (1997) uses the phrase Synopticonism to describe the capacity of the mass media to enable the many to watch the few in contrast to the Orwellian reading of Foucault that posits CCTV as part of the few watching the many. It is 'reality' shows that approach Mathiesen's concept; and high levels of interactivity are evident with webcasts, text messaging and phone voting. Perhaps, currently we have the few watching the few. Without directly intending to Norris and Armstrong (1999) show that many of the operatives of CCTV systems are as much couch potatoes (to the extent of taking in video tapes to watch on quiet shifts) and channel surfers as the rest of us. However, as we have seen operators 'will' suspects to commit a crime. They are often disappointed in this and their dream of power at a distance is further dashed on other occasions when 'something' 
does happen but the police seize control of the system - sitting themselves in the Director's chair?

\section{$\underline{\text { Back to Top } \quad \underline{\text { Back to Cultural }} \quad \text { Back to Surveilling }}$}

\section{The Director's Cut}

How might all this material be edited and presented? Literally it has been edited in the interface between my intentions and capacity on a word processor that renders each keystroke into digital code. Similarly I can, and do, edit sound and picture files. This whole production from storyboard to script to action to editing and post-production has been my responsibility and can be done from my chair. Still greater possibilities arise from more powerful technologies used by teams supported by State or Capital. The technologies might be neutral but the results of their use are not. Clearly camera surveillance can be used by the powerful and occasionally the organised powerless. Thus CCTV and mobile police video camera operatives can capture the actions of protestors for later evidential and intelligence use but increasingly the demonstrators too have cameras and websites and video distribution systems. Moreover the whole scene may be captured by the commercial media. Whose reality footage is then to be believed? Fetveit (1999: 797) notes: [the] paradox, of the simultaneous loss of faith in photographical images and the proliferation of reality TV and visual evidence.

Dovey argues that CCTV footage is seen to be 'real' because,

The CCTV image appears to simply calibrate visual perception; it is operated by a machine, and no human mediation is involved in its production of 'pure' evidence. (2001: 136)

Fetveit's argues that the 'camera-doesn't-lie' discourse of evidential credibility - whether in court room or for the Big Brother audience - is not effected by the increased capacity for and knowledge of digital manipulation of images because we compartmentalise. Thus we know that the police and the producers of Reality TV can - and may even have improve on the truth but the public/jury currently accepts photographic evidence within discourse of 'Reality' or 'Evidence'. Alongside that popular TV/video/cine entertainment increasingly relies on digital manipulation to produce a shiny new hyperreal. It is, perhaps, a mark of Elton's (2002) unsophistication in matters digital that sees the murderer in his novel use the simple staging of events and switching of tapes to achieve the desired effect - that they, the murderer was not at the scene of the crime but in the Director's chair.

Newburn and Hayman are quite correct to point out - like Lyon (1994) - that surveillance has two faces which act/appear simultaneously: 'one that intrudes and impacts on privacy, and one that watches and, potentially, protects' (2001:3). The Doncaster Commander has his own spin on the Big Brother question: 
If I had a Big Brother that watched over my car all day whilst I was at work, that ensured I could walk the streets in safety. I'd be more than pleased. (quoted in Mawby, 2001: 145)

Police in the United States might point out to him the perils of cameras in the hands of civilians. The beating of Rodney King, and others more recently, lead to a breakdown in law and order and police/community relations ${ }^{16}$. Moreover, the evidential quality was brought into relief by the acquittal of the officers involved. Juries can tur n a 'blind eye'.

Newburn and Hayman's research makes good claims for the protection of those detained in police cells and those guarding them and the potential reassurance of the community. Indeed widening surveillance back out from cameras to its sociological origins we find another of what might be called Lyon's 'little brothers' (1994) - medicine. Imagine a patient on life-support in an intensive care unit. Every body function is monitored and, in some cases, assisted or replicated. Clearly such invasive monitoring impacts upon privacy, and often dignity, yet it protects. We accept the catheter in hospital but feel Big Brother is taking the piss when it comes to public space.

Turning back to Big Brother we find that this protection by intrusion (Big Parent if you like) theme again. Whilst there was a voyeuristic thrill, for some, in seeing a number of the women contestants lolling in the bathtub together the intrusion of the cameras was, in part, protective. Imagine a number of men and women locked together in a house or on an island without cameras - Survivor or Temptation Island would turn into Lord of the Flies. At the expense of their privacy they gained the possibility of teasing the man (Paul) who came to the door to look and preventing sexual assault or rape. Other crimes may have been prevented too such as 'domestic' violence between the contestants. Indeed, given the age range of the contestants, drug taking might have been expected but was severely curtailed (students with whom I have discussed this issue claim they saw some). So, whilst, in Elton's (2001) novel the first persons to report the murder in the house were viewers I know of no crime reports for the Big Brother House. This reflects the protection/invasion dialectic. However I want to propose something more radical.

Whilst I have been, with Lyon (2000), critical of the extremes of post-modernism I do believe the modernist insistence on privacy - even the feminist one of Virginia Woolf's Room of One's Own - is ultimately misguided. We need to take the existence of 'community' - with its many faults - from the pre-modern where everyone knew our business and the post-modern scepticism about the existence of the self to embrace what is good, or at least unavoidable, about surveillance and to resist what is bad about it. That is intimacy not privacy should be valorised. Thus as Jane Austen says in her novel Northanger Abbey, 'consider the dreadful nature of the suspicions you have entertained. [..] Could they be perpetrated without it being known in a country like this, where social

${ }^{16} \mathrm{CNN}$ : http://www.cnn.com/2002/US/07/14/police.beating.videos.ap/index.html 
and literary intercourse is on such a footing; where every man is surrounded by a neighbourhood of voluntary spies...' (1969: 197-198) ${ }^{17}$.

Whilst surveillance, and often specifically CCTV, is seen by its opponents to be bad or potentially bad it is argued that it is inevitable and often welcomed by many. Indeed the success of websites like Friends Reunited, the growth in personal websites and the numbers auditioning for Big Brother shows many people are seeking to increase their visibility. However this is not to argue for acquiescence. CCTV is expensive and is the latest in a long line of 'techo-fixes' for crime problems - identity cards looks to be the next one. Even the Home Office's own guidance warns against unthinking use of CCTV. In their guide (Home Office, 1994) they suggest that the problem is examined, possible solutions sketched out and data collected before deciding on the actual solution which might include CCTV. For instance, damage to cars in one town was shown not to be the result of vandals, as had been thought. Research into which days and times the damage occurred showed it to be caused by careless market traders as they set up. CCTV would have been an expensive and unnecessary way to have controlled this. Even a cursory analysis of local press coverage reveals enormous pressure on councils from local media (Confirmed in interviews with Malcolm Powell, Editor of the Lynn News and John Pitt, Director of Corporate Services, Doncaster Council). So CCTV should be resisted where it is not the solution to the problem and, where it has been part of the solution all the credit should not go to it. More sensitive policing and changes in the culture and even architecture of town centres may contribute more and answer the implicit critique of Ballard (2000) about 'civic sense'.

Instead of arguing for an insular and isolating privacy we need greater intimacy, a slightly grubby organicism not the sterility of the cleansed mall bathed in aseptic light and captured on video. This may require greater transparency. The nature of modern 'celebrity' gives us some clues as to how this might work. The modern celebrity is always the subject of our gaze and often invites its intrusions but then, footballer or supermodel, seeks privacy. Thus while most of us would not wish to lead lives under the surveillance of the paparazzi a more democratic model would be for us to spend less time looking at celebrity and more time looking at ourselves. Perhaps I am describing an 'omnicon' where all watch, or might potentially, watch all. CCTV would then only be objectionable for being closed and our resistance should be aimed at cameras and systems which are not fully democratic.

Moreover, (like Ferrell, 1995) I would claim that no understanding of surveillance, particularly CCTV surveillance can be fully understood without reference to some of the disciplines deployed here; including artistic, literary and popular. That is to accept that the title of this article is a false opposition - CCTV is both crime control and crime culture TV and neither of those things. Moreover, the connection between culture and crime goes two ways - a Spiderman comic is said to have inspired electronic tagging (Staples, 2000:43).

\footnotetext{
${ }^{17}$ See Persuasions On-Line discussion of Austen's Northanger Abbey: http://www.jasna.org/pol01/wiesenfarth.html and http://www.jasna.org/pol02/schaub.html.
} 
The consequences of this for studies of surveillance is that we cannot simply reject it as invasive when we seem to welcome invasion - or at least ride along with the invasion of others like the reporters on Cops. And, where we seek to resist it - as we should, where its expense and inefficiency are disproportionate - we should look for solutions that work with the culture. As Staples argues, 'after all [..] much of what we live today is grounded in a legacy of Western thought and practice dating back several centuries' (2000:158) and if active resistance is chosen it must be 'in the form of "local" micropractices [...] our homes, workplaces, schools and communities' (2000:158).

Thus if we treat the cameras as more of a medium we may denaturalise them and break the spell of naturalism/realism - the lights go up and we find we are in a cinema. Studies of camera operatives and control rooms should borrow from film studies and from feminism to explore the penetrative ideal of the system. Moreover, we should expect so protean a medium to elude the restrictions placed on it by modernist legislation just as Hollywood eventually 'used' the Hay's Code restrictions to suggest more fully what they had previously shown. And finally, I would hope that other disciplines than psychology might be invited to commentate on Big Brother.

Back to Top

\section{References}

Armstrong, G. and Giulianotti, R. (1998) From another angle: police surveillance and football supporters. In C. Norris, J. Moran and G. Armstrong (eds.) Surveillance, Closed Circuit Television and Social Control Aldershot: Ashgate, 113-135.

Austen, J. (1969) Northanger Abbey. Ed. R. W. Chapman, 3rd ed., Oxford: Oxford University Press.

Ballard, J. G. (2000) Super-Cannes. London: Flamingo.

Bogard, W. (1996) The Simulation of Surveillance. Cambridge: Cambridge University Press

Fishman, M. and G. Cavender, (eds.) (1998) Entertaining Crime: Television Reality Programs. New York: Aldine De Gruyter.

Dandeker, C. (1990) Surveillance, Power and Modernity. Cambridge: Polity Press.

Davies, S. (1995) Welcome Home Big Brother. Wired, May 1995: 58-62

Ditton, J. and E. Short, (1998) Evaluating Scotland's first town centre CCTV scheme. In C. Norris, J. Moran and G. Armstrong (eds.) Surveillance, Closed Circuit Television and Social Control Aldershot: Ashgate, 155-174. 
Dovey, J. (2001) Big Brother. In G. Creeber (ed.) The Television Genre Book London: BFI publishing, 136-137

Ellul, J. (1980) The Technological System. New York: Continuum.

Elton, B. (2001) Dead Famous. London: Bantam Press.

Fenichel, O. (1999) The scoptophilic instinct and identification. In J. Evans and S. Hall (eds.) Visual Culture: the reader London: Sage.

Ferrell, J. (1995) Style Matters: Criminal Identity and Social Control. In J. Ferrell and C. Sanders (eds.) Cultural Criminology, Boston: Northeastern University Press, 169189.

Fetveit, A. (1999) Reality TV in the Digital Age. Media, Culture and Society 21(6): 787804.

Gill, M. and Turbin, V. (1998) CCTV and shop theft: towards a realistic evaluation. In C. Norris, J. Moran and G. Armstrong (eds.) Surveillance, Closed Circuit Television and Social Control. Aldershot: Ashgate, 189-206.

Graham, S. (1998) Towards the fifth utility? On the extension and normalisation of public CCTV. In C. Norris, J. Moran and G. Armstrong (eds.) Surveillance, Closed Circuit Television and Social Control. Aldershot: Ashgate, 89-112.

Groombridge, N. and Murji, K. (1994a) CCTV and Policing. Criminal Justice Matters, 17, Autumn 1994: 9.

Groombridge, N. and Murji, K. (1994b) As Easy as AB and CCTV? Policing 10(4), Winter 1994: 283-290

Groombridge, N. (1998) The Car and Crime: Critical Perspectives. Unpublished PhD: Middlesex University.

Home Office (1994) CCTV: Looking Out For You. London: HMSO.

Lemire, E. (2000) Voyeurism and the Post War Crisis of Masculinity. In J. Belton Alfred Hitchcock's Rear Window. Cambridge: Cambridge University Press.

Lyon, D. (1994) The Electronic Eye: The Rise of Surveillance Society. Cambridge, Polity Press.

Lyon, D. (2001) Surveillance Society: Monitoring Everyday Life. Buckingham: Open University Press. 
Marx, G. (1995) Electric Eye in the Sky: Some Reflections on the New Surveillance and Popular Culture in J. Ferrell and C. Sanders (eds.) Cultural Criminology, Boston: Northeastern University Press: 106-141. (also http://www.garymarx.net)

Mathiesen, T. (1997) The viewer society: Michel Foucault's 'Panopticon' revisited. Theoretical Criminology 1(2): 215-234.

Mawby, R. C. (2002) Policing Images: Policing, Communication and Legitimacy. Cullompton: Willan.

McCahill, M. (2002) The Surveillance Web: The Rise of Visual Surveillance in an English City. Cullompton: Willan.

Mulvey, L. (1999) Visual Pleasure and Narrative Cinema. In J. Evans and S. Hall (eds.) Visual Culture: the reader. London: Sage.

Newburn, T. and S. Hayman, (2001) Policing, Surveillance and Social Control: CCTV and police monitoring of suspects. Cullompton: Willan.

Norris, C., J. Moran and G. Armstrong (eds.) (1998) Surveillance, Closed Circuit Television and Social Control. Aldershot: Ashgate.

Norris, C. and G. Armstrong, (1999) The Maximum Surveillance Society: The Rise of CCTV. Oxford: Berg Publishers.

Peelo, M. and K. Soothill, (2000) The place of public narratives in reproducing social order. Theoretical Criminology 4(2): 131-148.

Sharff, S. (1997) The Art of Looking in Hitchcock's Rear Window. New York: Limelight Editions.

Skinns, D (1998) Crime reduction, diffusion and displacement: evaluating the effectiveness of CCTV', in C. Norris, J. Moran and G. Armstrong (eds.) Surveillance, Closed Circuit Television and Social Control. Aldershot: Ashgate, 175-188.

Staples, W.G. (2000) Everyday Surveillance: Vigilance and Visibility in Postmodern Life. Oxford: Rowman and Littlefield.

Tagg, J. (1999) Evidence, truth and order: a means of Surveillance. in J. Evans and S. Hall (eds.) Visual Culture: the reader, London: Sage Publications.

Virilio, P. (1986) Speed and Politics. New York: Semiotexte. 